\title{
Генофонд хлопчатника по форме листовой пластинки и физиологическая селекция новых сортов
}

Абдуллаев $X$. . $^{I^{*}}$, д.б.н., зав. лабораторией «Фотосинтез и продуктивность растений»; Негматов М.Н.' ${ }^{2}$ к.б.н., зав. лабораторией генетики хлопчатника Отдела общей биологии и биотехнологии растений; Негматов Б.М.' н.с.; Саиднабиев М.M. ${ }^{2}$, с.н.с.

${ }^{1}$ Институт ботаники, физиологии и генетики растений Академиинаук Республики Таджикистан, г. Душанбе, Таджикистан;

${ }^{2}$ Худжандский научный центр АН Республики Таджикистан.

*e-mail: homidjon1945@mail.ru

Выявлена возможность и показана необходимость использования физиологических признаков, в частности, формы листовой пластинки в селекции высокоурожайных сортов хлопчатника, устойчивых к экстремальным факторам среды и вредителям. Путем гибридизации рассеченолистной формы Л-461 с клейстогамной линией КЛ-5 создан окралистныйклейстогамный сорт средневолокнистого хлопчатника «20-солагии Истиқлолият» с урожайностью 40-45 й/га.

Ключевые слова: хлопчатник, генофонд, формы листовой пластинки, физиологическая селекичи, сорт.

Cotton genofond on shape leaf blades and physiological selection a new variety Abdullaev Kh.A, *Negmatov M.H., Negmatov B.M, Saidnabiev M.M. *Institute of Botany, Plant Physiology and Genetics, Khudjand Scientific Center, Academy of Sciences of the Republic of Tajikistan.

Possibility and necessary of using physiological features, in particular, the shape of the leaf blades in the selection of high-yielding varieties of cotton, resistant to extreme environmental factors and pests, were revealed. By hybridization of the okra leaf line L-461with cleistogamous KL-5 wascreated a new middle staple variety of cotton "Twentieth an anniversary of Istiqloliyat" with a yield of 40-45 c/ha.

Key words: cotton, genofond, leaf blades shape, physiological selection, variety.

Генофонд растений хлопчатника характеризуется широкой амплитудой изменчивости формы листовой пластинки. В изменчивости формы листа имеется ряд переходов от видов хлопчатника, характеризующихся цельным (без лопастей) (рис. 1Д и 1Е), округлым (без заостренных верхушек), чашеобразным, ланцетовидным, нитевидным листом, до видов хлопчатника с пальчатодольчатым (рис. 1Г), рассеченным (рис. 1Б) и сильнорассеченным 
листом (рис. 1А) [1].

Цельнолистные формы среди культивируемых видов хлопчатника почти не встречаются. Цельные листья (ланцетовидной, яйцевидной и округлой формы), не изменяющиеся в онтогенезе, свойственны древним формам и диким видам хлопчатника (G. davidsonii, G. sturtii, G. raimondii, G. armourianum, G. aridum, G. klotzschianum), и они появляются в виде спонтанных ииндуцированных мутаций, а также при инбридинге и гибридизации.
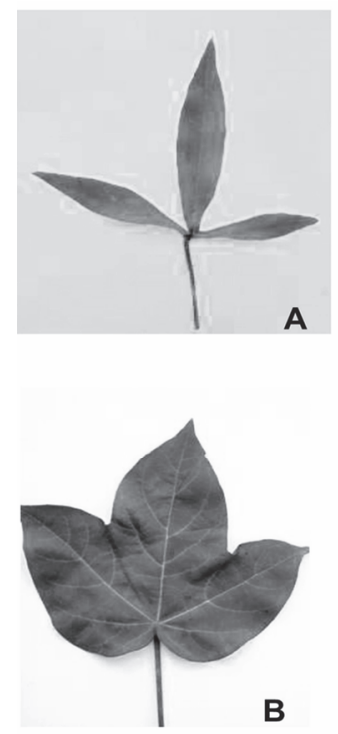

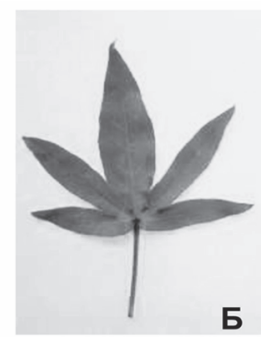

Б

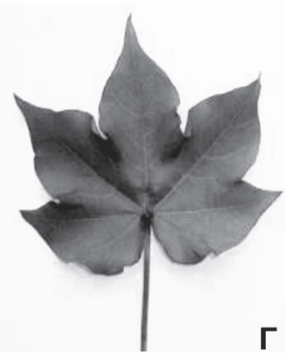

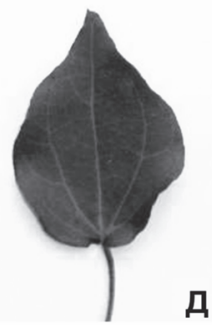

Д

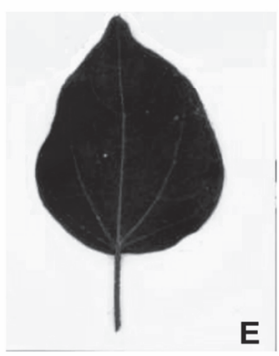

Рис. 1. Формы листовой пластинки у хлопчатника Gossypium hirsutum L. A - трёхрассечённая, Б - пальчаторассечённая, В- трёхраздельная, Г- пальчатодольчатая, Д- цельнолистная (зелёной окраски), Е- цельнолистная (антоциановой окраски).

В мутационной изменчивости признака «форма листовой пластинки» G. hirsutum L. Проявляются такие фенотипы листьев, которые характерны для листьев других видов рода Gossypium: пальчато-рассеченный (G. triphyllum Harv. Horhr. G. robinsonii F. Mull., G. arboreum L.), цельнокрайний (G. thurberi Tod. G. armourianum Kearney, G. harknesii Brandy.), трехлопастной (G. somalense (Gurke) H.S. et St., G. areysianum (Deflers) H.S., G. incanum (Schwartz) Hillcoat) и другие.

По имеющимся литературным данным [1], у хлопчатника вида G. hirsutum L., как правило, встречаются две формы листьев - пальчатодольчатая и пальчаторассеченная. Промышленные сорта этого вида, высеваемые в разных хлопковых зонах мира, имеют преимущественно пальчатодольчатую форму листьев. 
Горизонтально расположенные (планофильное) пальчатодольчатые листьях лопчатника в фазе массового цветенияв посеве способствуют смыканию рядков растений, затенению (до 75-85 \%) междурядья и листьев нижнего яруса и, тем самым, ухудшают радиационный, температурный иаэродинамический режим посева, снижают продуктивность. Наоборот, рассеченные и сильнорассеченные формы листа (растения с такими листьями имеютменьший листовой индекс $-2,8 \mathrm{~m}^{2} / \mathrm{M}^{2}$, растения с нормальными листьями $-4,6 \mathrm{~m}^{2} / \mathrm{M}^{2}$ ) способствуют улучшению светового, теплового и аэродинамического режима посева, что, в конечном итоге, приводит к повышению продуктивности фотосинтеза и урожая. Обычно сорта и линии с нормальной (пальчато-дольчатой) и рассеченной формой листовой пластинки дают приблизительно одинаковый урожай. Как правило, окралистные и суперокралистные формы являются скороспелыми.

Формы с рассеченным листом считаются перспективными и в селекции хлопчатника для повышения устойчивости этой культуры против хлопковой моли (розовый коробочный червь) и улучшения его хозяйственно ценных признаков [2]. Формы с рассеченным листом типа «окра» рекомендуются к использованию в практической селекции для выведения новых сортов хлопчатника, устойчивых к белокрылке [3] и снижения ее вредоносности. Поэтому при построении модели идеального типа средневолокнистого хлопчатника, предложенной для создания скороспелых, высокоурожайных и устойчивых к болезням и вредителям сортов, одной из важнейших характеристик было наличие рассеченной формы листовой пластинки [4]. Исходя из сказанного, этот признак был использован при выведении нового клейстогамного сорта средневолокнистого хлопчатника «20-солагии Истиқлолият» [5]. Сорт «20-солагии Истиқлолият» (рис. 2) обеспечивает получение 40-45 ц / га урожая хлопка-сырца с каждого гектара. Сорт районирован с 2011 г.

Авторы сорта - М.Н. Негматов, Х.А. Ахмедов, Б.М. Негматов, С.Т. Саидов (ТАСХН), Х.А. Абдуллаев (Академия наук Республики Таджикистан).

На сорт «20-солагии Истиқлолият» получены авторское свидетельство (А.С. № 72 от 10 октября 2011 г.) и патент на селекционное достижение (Патент РТ № 72 от 10 октября 2011 г.).

Сорт «20-солагии Истиқлолият» в истории мирового хлопководства является первым районированным клейстогамным сортом средневолокнистого хлопчатника и, в этой связи, в случае его широкого распространения (внедрения) в сельскохозяйственное производство, в фермерских и дехканских хозяйствах появляется возможность, что сами хозяйства могут себя обеспечить посевными семенами лучшего качества, без лишней затраты денег на приобретение элитных семян. Наличие строгого самоопыления у этого сорта позволяет сохранить чистоту сорта и обеспечить его долговре- 
менное нахождение в производстве, способствует значительному повышению однородности хлопкового волокна и других хозяйственно ценных признаков хлопчатника, важных для текстильной промышленности.

У клейстогамных сортов опыление и оплодотворение происходит в закрытом лепестками бутоне, независимо от сухости и влажности воздуха, следовательно, их можно выращивать в ксерофитных условиях маловодного засушливого климата или влажного, дождливого тропического климата.

Клейстогамные сорта могут существенно упростить процесс получения элитных семян и, тем самым, открыть новые возможности для налаживания элитно-семеноводческих работ.

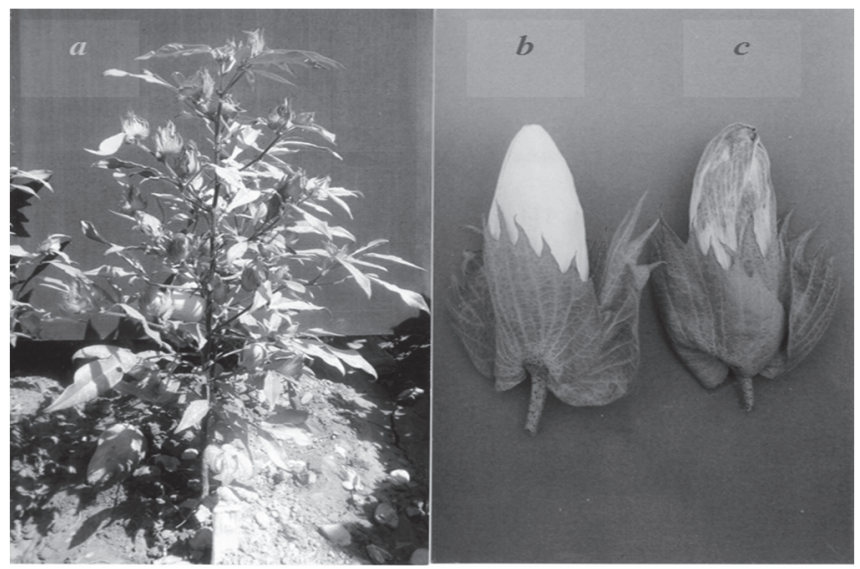

Рис. 2. $a$-куст хлопчатника сорта «20-солагии Истиқлолият»;

$b$ - клейстогамный (закрытый) цветок до оплодотворения; $c$ - цветок после оплодотворения.

\section{Список литературь}

1. Мауэр Ф.Н. Хлопчатник. Происхождение и систематика хлопчатника. Ташкент: Изд.-во АН Уз. ССР, 1954, Т. 1. - 383 с.

2. Wilson F.D. Relative resistance of cotton lines to pink bollworm// Crop Sciences. - 1990, - V. 30, № 3 - P. 500-504.

3. Мирзаева Г.А. Белокрылки в Узбекистане и устойчивость к ним различных сортов хлопчатника: Автореф. дис. ... канд. биол. наук / ВИЗР, ВАСХНИЛ: СанктПетербург, 1992, 21 с.

4. Насыров Ю.С., Домуллоджанов Х.Д., Абдуллаев Х.А., Асроров К.А. Морфологические и хозяйственно ценные параметры идеатипа средневолокнистого хлопчатника // С.-х. биология. - 1987, № 7. С. 33-36.

5. Негматов М.Н. Новый клейстогамный сорт средневолокнистого хлопчатника // Информационный листок. - Душанбе: НПИ Центр, 2011, сер. 68-35. С. 1-4. 